\title{
ОСОБЛИВОСТІ УЯВЛЕННЯ \\ ПРО СМЕРТЬ I ПЕРЕЖИВАННЯ СТРАХУ СМЕРТІ У ДІТЕЙ ІЗ ОНКОЛОГІЧНИМИ ЗАХВОРЮВАННЯМИ
}

\section{Скаковська А. В.}

\section{ВСТУП}

Ситуація онкологічного захворювання є травматичним досвідом як для дитини, так і для всієї сім’ї. Госпіталізація дитини із приводу онкозахворювання викликає стрес і тривогу, страх перед невідомою ситуацією. Під час потрапляння в лікарню й у процесі лікування психоемоційний стан та особистість дитини зазнають певних змін. У дитини, яка має онкопатологію, виникають питання про захворювання, про план лікування, формується уявлення про хворобу. Також зазнає змін самооцінка дитини, сприйняття власного «Я-образу», психосоціальна ситуація, відбуваються зміни в системі сім'ї. Переживання тяжкого захворювання, досвід госпіталізації, розуміння дитиною онкологічного діагнозу, важкий соматичний стан, зміни у зовнішньому вигляді, тривога дитини під час лікування, тривога та шоковий стан батьків, інвазивні маніпуляції, досвід смерті інших дітейпацієнтів у лікарні, переживання страхів і тривоги сприяють роздумам дитини про питання смерті, актуалізації екзистенційних страхів. За умов онкологічного стаціонару під впливом тяжкого соматичного захворювання в дитини можуть трансформуватися іiі уявлення та фантазії на тему смерті, уявлення про смерть можуть набути більш зрілого характеру, ніж до хвороби. Відчуття та розуміння дітьми того, що онкологічне захворювання є небезпечним і становить загрозу для функціонування та життя, викликає танатичну тривогу, зіштовхує маленького пацієнта з переживанням власного страху смерті.

Метою статті $\epsilon$ дослідження уявлення про смерть і вивчення особливостей переживання страху смерті дітьми молодшого шкільного віку в ситуації онкологічного захворювання.

\section{1. Особливості уявлення про смерть \\ у дітей з онкологічними захворюваннями}

Страх смерті у дітей тісно пов'язаний з уявленням про смерть і розумінням незворотності цього процесу. За S. Antony, процес проковтування, випльовування та процес сепарації є ранньою формою 
поняття смерті, а зрілою формою є усвідомлення дитиною смерті як кінцевої події ${ }^{2}$.

M. Nagy виділила три стадії розуміння смерті дітьми. Перша стадія (до 5 років) - діти вважають смерть сном, від’їздом. Друга стадія (6-9 років) діти починають розуміти кінцевість смерті, проте не розуміють іiі неминучості та справжньої причинності. Смерть уявляється як кінцева подія, якої можна уникнути і яка відбувається виключно із зовнішніх причин. Третя стадія (після 9 років) - розуміння смерті включає той факт, що смерть $є$ не тільки незворотною, а й неминучою. M. Nagy відзначає цю стадію як заключну в розвитку розуміння смерті ${ }^{2}$.

A. Gessell, F. Ilgs визначили такі етапи розвитку розуміння смерті. До 5 років діти сприймають ії неемоційно. Із 6 років у дитини виникає емоційна реакція на смерть. Вік 7 років характеризується інтересом дитини до теми смерті та поховання. У віці 8 років діти починають розуміти те, що смерть неминуча, й усвідомлювати власну смертність ${ }^{3}$.

За Бачинським, дитина 6 років усвідомлює зникнення біологічних функцій. Також на дитину впливають культурні чинники, від яких інформація про смерть приймається вибірково, залежно від зовнішніх факторів. У 7 років вже сформований певний набір понять про смерть (зміна постави і зовнішнього вигляду тіла, відсутність рухів і відчуттів, зупинка функціонування серця і дихання). Діти віком 8-10 років можуть пояснити незворотність смерті, спираючись на релігійний вимір ${ }^{4}$.

J. Binnebesel вказує на те, що роздуми про власну смерть властиві лише невеликій кількості дітей, за винятком тих, котрі пережили довгу або важку хворобу. Для більшості дітей смерть асоціюється зі старістю, а не 3 ними самими 5

У вивченні страху смерті й особливостей уявлення про смерть досліджуваних дітей 3 онкологічними захворюваннями взяли участь 77 хлопчиків і 75 дівчаток. Вибірку дослідження склали 152 дитини віком від 6 до 10 років, що лікувалися від онкогематологічних хвороб у відділенні гематології та інтенсивної хіміотерапії Західноукраїнського спеціалізованого медичного центру (м. Львів), Обласної дитячої

${ }^{1}$ Antony S. The discovery of death in childhood and after. Publisher: Basic Books, 1972. 280 p.

${ }^{2}$ Nagy M. The child's theories concerning death. The Pedagogical Seminary and Journal of Genetic Psychology. 1948. № 3. P. 3-27.

${ }^{3}$ Gessell A., Ilgs F.L., Ames L.B. The Child from Five to Ten. Published by New York and London : Harper \& Brothers, 1946. 475 p.

4 Binnebesel J. Opieka nad dziećmi i młodzieżą $\mathrm{z}$ chorobą nowotworną w doświadczeniu pacjentów. Toruń : Wyd. Uniwersytetu Mikołaja Kopernika, 2003. 333 s.

5 Біннебезель Й., Католик Г. Паліативно-хоспісна опіка: позамедичні багатовимірні аспекти : монографія / за ред. Й. Біннебезель, Г. Католик. Львів : Український Католицький Університет ; Nowa Wieś : Wydawnictwo Rolewski, 2018. $360 \mathrm{~s}$. 
клінічної лікарні (м. Рівне), дитячій клініці «Бамбіно Джезу» (м. Рим), Університетській дитячій клініці (м. Люблін).

Пацієнти, які проходили лікування у закордонних клініках, були опитані нами під час перебування в Україні у перерві між хіміотерапією та під час перебування на амбулаторному лікуванні у тракті підтримуючої терапії. Усі діти взяли участь у дослідженні за згодою батьків або опікунів.

Контрольну групу нашого дослідження склали 152 відносно здорові дитини, котрі не мали хронічних захворювань. Серед них 88 дівчаток i 64 хлопчики віком від 6 до 10 років, які проходили амбулаторне лікування у Західноукраїнському спеціалізованому дитячому медичному центрі (м. Львів), приватній поліклініці «Мініполіклініка» (м. Львів) із приводу таких хвороб, як ангіна, ГРВІ, гастрит, отит, бронхіт, захворювання ЖКТ, алергічний дерматит.

Для дослідження особливостей уявлення про смерть і переживання страху смерті у дітей з онкологічними захворюваннями нами були використані такі методики: авторська анкета для батьків (А. Скаковська), опитувальник дитячих страхів (О. Захаров), шкала «Страх смерті» була розмежована нами на окремі шкали: «Страх власної смерті» та «Страх смерті своїх батьків», що дозволило конкретизувати, який саме страх смерті $\epsilon$ домінантним. Також у дослідженні застосовувалися: авторський опитувальник дитячих страхів (А. Скаковська), проективна методика «Кактус» (М. Панфілова), методика «Мої почуття» (А. Скаковська), малюнок «Образ хвороби», дитячий аперцептивний тест (Л. Беллак, С. Беллак), схема аналізу адаптивних механізмів (М. Howort), анкета «Уявлення про смерть» (на основі досліджень Д. Ісаєва).

Нами були використані такі методи опрацювання результатів, як: якісний аналіз, порівняльний аналіз (t-test Стьюдента) та кореляційний аналіз Ч. Спірмена.

У ході вивчення особливостей уявлення про смерть серед дітей із онкологічними захворюваннями було проведено опитування з метою вивчення розуміння смерті дитиною. Кожному опитаному були поставлені питання: 1) «Чи ми безсмертні?», 2) «Чи може смерть статися 3 дитиною?», 3) «Що таке смерть?». Якісний аналіз відповідей досліджуваних на питання про смерть подано у вигляді двох діаграм. Як видно 3 рис. 1, основна кількість онкохворих дітей відповіли на питання про безсмертність людини «ні» $(96,1 \%$ опитаних, 146 дітей), а решта (6 дітей) - «так». Відповіді на запитання «Чи може смерть статися з дитиною?» поділили опитаних на тих, хто вважає, що «так»це більша частина (63,8\% від групи, 97 дітей), і тих, хто переконаний, що смерть не може статися з дитиною (36,2\% опитаних, 55 дітей).

На запропоноване дітям 3 онкологічними захворюваннями питання «Що таке смерть?» домінантною відповіддю опитаних було «коли 
людина (душа) вирушає до раю» (19,7\% опитаних, 30 дітей) і «зустріч із Богом, ангелами» (17,1\% опитаних, 26 осіб), 9,9\% опитаних дітей вважають смерть чимось дуже страшним (15 дітей із групи), а 5,9\% дітей називають іiі кінцем життя (9 дітей). Дехто з опитаних назвав смерть «відсутністю болю та страждань» (3,9\%, 6 дітей).

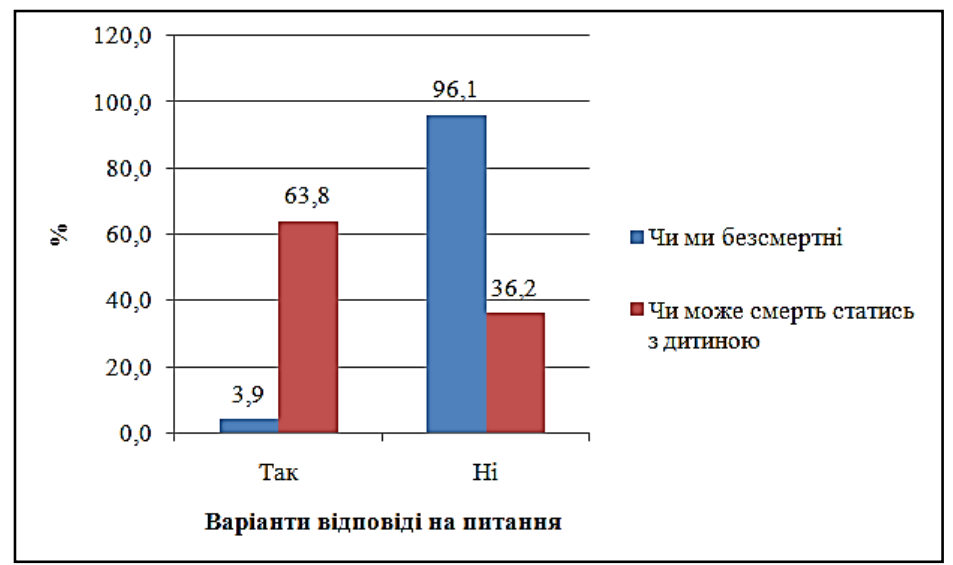

Рис. 1. Відсотковий розподіл досліджуваних дітей з онкологічними захворюваннями за відповідями на питання анкети «Усвідомлення смерті»

Також досліджувані онкохворі вважають смерть «сном» (4,6\% опитаних, 7 дітей), «темрявою» (3,9\% опитаних, 6 дітей). Серед відповідей були варіанти «смерть - це похорон, кладовище» (4,6\% опитаних, 7 дітей), «смерть - це зустріч із померлими» (4,6\% опитаних, 7 дітей), «смерть - це нерухомість, неможливість дихати» (3,9\% опитаних, 6 дітей). Іншими варіантами відповідей на питання опитувальника були «не знаю» та «неможливість думати та відчувати» (рис. 2).

У ході вивчення особливостей уявлення про смерть і переживання страху смерті були опитані відносно здорові діти з контрольної групи, які не хворіли на онкологічні захворювання. Нижче наведені результати відповідей опитаних осіб на питання про усвідомлення смертності людини. Розподіл відповідей (рис. 3) свідчить про те, що більшість дітей усвідомлюють смертність людини (89,5\% опитаних, 136 дітей), більше половини вважають, що смерть може статися 3 дитиною (57,2\% опитаних, 87 осіб). 


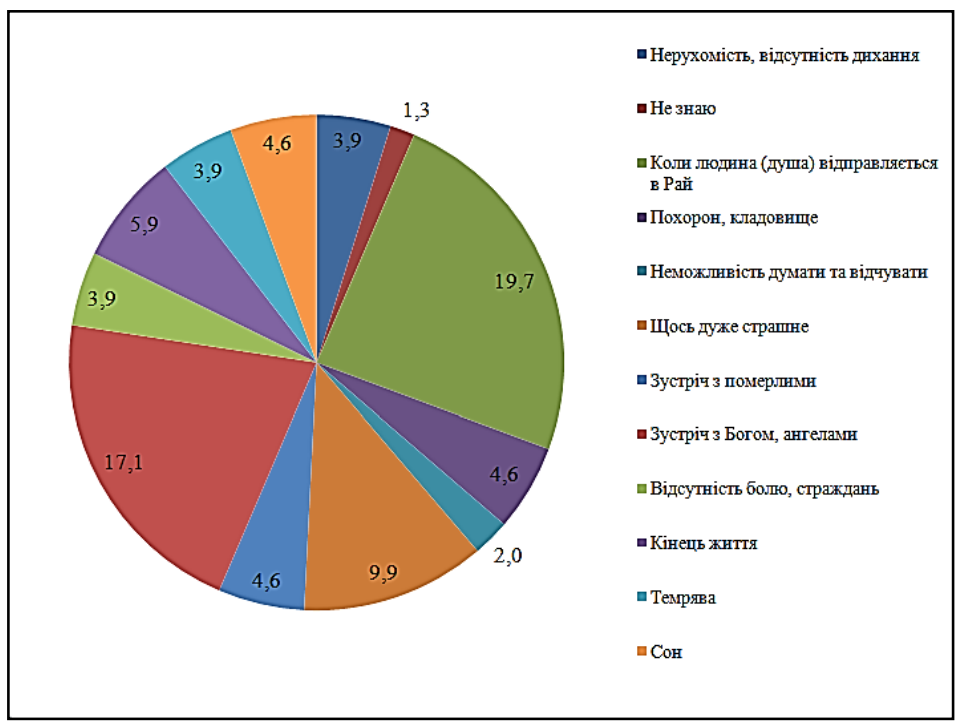

Рис. 2. Відсотковий розподіл відповідей досліджуваних дітей із онкологічними захворюваннями на питання «Що таке смерть?»

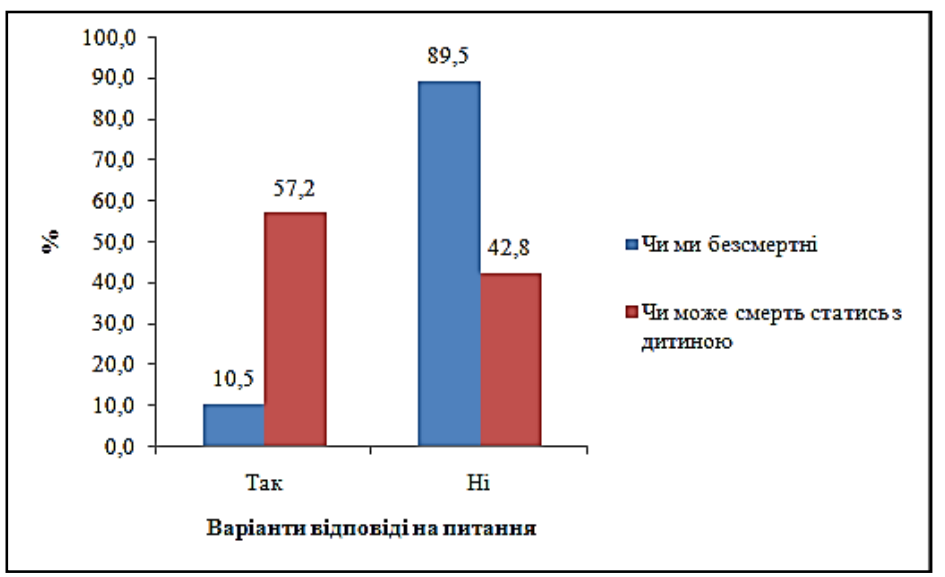

Рис. 3. Відсотковий розподіл досліджуваних дітей із контрольної групи за відповідями на питання опитувальника «Усвідомлення смерті»

Другою частиною дослідження «Усвідомлення смерті» було завдання відповісти, що таке смерть. Опитувалися діти 3 контрольної групи (рис. 4). Найбільш часті відповіді стосуються опису стану 
«нерухомості, відсутності дихання» (26,3\% опитаних), $11,2 \%$ опитаних вважають, що «смерть - це коли людина (душа) вирушає до раю, зустрічається з Богом», для 15,2\% опитаних «смерть - це кінець життя» та для $10,5 \%$ «смерть - це щось дуже страшне». На відміну від досліджуваних з онкологічними захворюваннями, у контрольній групі ніхто 3 дітей не охарактеризував смерть як відсутність болю, страждань. Для вивчення особливостей уявлення про смерть необхідно дослідити психологічні відмінності між опитаними онкохворими дітьми 3 досліджуваної групи 3 різним ступенем усвідомлення смертності людини й уявленням про те, чи смерть може статися 3 дитиною. Розподіл досліджуваних за схильністю вважати, що людина смертна, така: 146 онкохворих дітей вважають, що людина смертна, 9 опитаних відповіли, що людина безсмертна. За допомогою порівняльного аналізу встановлено статистично значущі відмінності за такими шкалами: «хвороба - це темрява» $\left(\mathrm{x}_{\text {смертна. }}=0,07, \mathrm{x}_{\text {безсмертна }}=0,33\right.$ відповідно при $\mathrm{t}=-2,39 \mathrm{p}=0,02)$, «хвороба - людина в ліжку» $\left(\mathrm{x}_{\text {смертна. }}=0,01, \mathrm{x}_{\text {безсмертна }}=0,33\right.$ відповідно при $\left.\mathrm{t}=-5,17 \mathrm{p}=0,00\right)$, «смерть може статися 3 дитиною» ( $\mathrm{x}_{\text {смертна. }}=0,84, \mathrm{x}_{\text {безсмертна }}=0,00$ відповідно при $\mathrm{t}=5,49 \mathrm{p}=0,00), \quad$ «смерть - це $\quad$ сон» $\quad\left(\mathrm{x}_{\text {смертна. }}=0,03, \quad \mathrm{x}_{\text {безсмертна }}=0,50\right.$ відповідно при $\mathrm{t}=-5,96 \mathrm{p}=0,00)$.

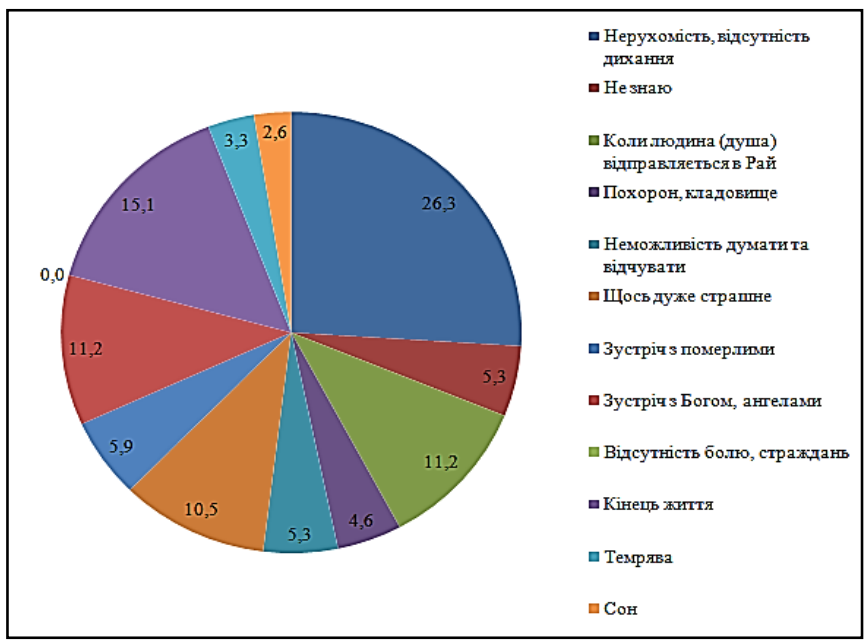

Рис. 4. Відсотковий розподіл відповідей досліджуваних дітей із контрольної групи на питання методики «Що таке смерть?»

Ці результати свідчать про те, що опитані онкохворі діти, які вважають людей смертними, визнають, що смерть може статися 
3 дитиною. На відміну від них діти, які вважають, що люди $\epsilon$ безсмертними, схильні вважати хворобу темрявою, зображати хворобу у вигляді людини в ліжку. Також їм притаманне уявлення про смерть як про сон.

Відповіді на питання «Чи може смерть статися 3 дитиною?» розподілили опитаних 3 онкологічними хворобами на дві підгрупи: 30 опитаних вказали, що смерть не може статися 3 дитиною, тоді як 122 дитини відповіли ствердно на поставлене запитання. Таким чином, порівняння осіб із цих двох підгруп дозволило виявити такі відмінності у сприйнятті власної хвороби за шкалами: «хвороба - це привид, скелет» $\quad\left(\mathrm{x}_{\text {дитина смертна. }}=0,09, \mathrm{x}_{\text {безсмертна }}=0,23\right.$ відповідно при $\mathrm{t}=-2,19$ $\mathrm{p}=0,03)$, «хвороба - це ліки, крапанки, уколи» $\left(\mathrm{x}_{\text {дитина_смертна. }}=0,42\right.$, $\mathrm{x}_{\text {безсмертна }}=0,13$ відповідно при $\left.\mathrm{t}=2,97 \mathrm{p}=0,00\right)$. Відмінності у сприйнятті смерті такі: «смерть - це зустріч із Богом, ангелами» ( $\mathrm{x}_{\text {дитина_смертна. }}=0,25, \mathrm{x}_{\text {безсмертна }}=0,03$ відповідно при $\left.\mathrm{t}=2,70 \mathrm{p}=0,01\right)$, «смерть - це темрява» ( $\mathrm{x}_{\text {дитина смертна. }}=0,02, \mathrm{x}_{\text {безсмертна }}=0,13$ відповідно при $\mathrm{t}=-3,01 \mathrm{p}=0,00)$, «смерть - це сон» $\left(\mathrm{x}_{\text {дитина_смертна. }}=0,01, \mathrm{x}_{\text {безсмертна }}=0,20\right.$ відповідно при $\mathrm{t}=-4,77 \mathrm{p}=0,00)$. Ці результати означають, що досліджувані, які вважають, що смерть може статися 3 дитиною, асоціюють хворобу з образом привида, скелета, а смерть - із зустріччю 3 Богом, ангелами більшою мірою, ніж решта опитаних пацієнтів 3 онкологічними захворюваннями. Зображення хвороби як образу привида, скелета також може свідчити про усвідомлення дитиною тяжкості захворювання.

На відміну від них діти, які не визнають, що смерть може статися 3 дітьми, характеризуються тим, що вважають хворобу ліками, крапанками, уколами та позначають смерть в образі темряви, сну. Це може вказувати на те, що ця категорія дітей асоціює хворобу 3 медичними маніпуляціями й не до кінця усвідомлює небезпеку свого захворювання. Розуміння дітьми смерті як сну та темряви також може вказувати на нерозуміння їі незворотності.

Додатково в ході декількох порівняльних аналізів було виявлено, що більшим усвідомленням смертності людини володіють опитані пацієнти з онкологічними захворюваннями, які мають досвід стосунку зі смертю ( $\mathrm{x}_{\text {досвід. }}=0,00, \mathrm{x}_{\text {нема_досвіду }}=0,15$ відповідно при $\left.\mathrm{t}=-4,42 \mathrm{p}=0,00\right)$; опитані, котрі знають про свій діагноз $\left(\mathrm{x}_{\text {знає }}=0,03, \mathrm{x}_{\text {не знає }}=0,17\right.$ відповідно при $\mathrm{t}=-2,39 \mathrm{p}=0,02)$; діти, які характеризуються вираженими страхом смерті ( $\mathrm{x}_{\text {вир_страх }}=0,08, \mathrm{x}_{\text {не_вир_страх }}=0,00$ відповідно при $\mathrm{t}=2,68$ $\mathrm{p}=0,01)$, страхом темноти $\left(\mathrm{x}_{\text {вир_страх }}=0,00, \mathrm{x}_{\text {не_вир_страх }}=0,08\right.$ відповідно при $\mathrm{t}=-2,4 \mathrm{p}=0,01)$, страхом перед болем під час смерті ( $\mathrm{x}_{\text {вир_страх }}=0,00$, $\mathrm{x}_{\text {не вир страх }}=0,15$ відповідно при $\left.\mathrm{t}=-4,3 \mathrm{p}=0,00\right)$, страхом розлуки 3 батьками після смерті ( $\mathrm{x}_{\text {вир_страх }}=0,00, \mathrm{x}_{\text {не_вир_страх }}=0,38$ відповідно при

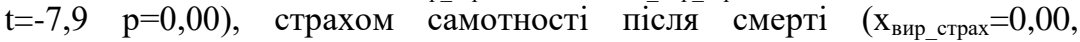
$\mathrm{X}_{\text {не вир страх }}=0,21$ відповідно при $\left.\mathrm{t}=-5,78 \mathrm{p}=0,00\right)$. Щодо схильності 
вважати, що смерть може статися 3 дитиною, то більше ця думка притаманна пацієнтам 3 онкологічним захворюванням із більшим досвідом стосунку зі смертю $\left(\mathrm{x}_{\epsilon \_ \text {досвід }}=0,90, \mathrm{x}_{\text {нема_досвіду }}=0,52\right.$ відповідно при $\mathrm{t}=5,62 \mathrm{p}=0,00)$; опитаним, котрі знають про свій діагноз $\left(\mathrm{x}_{3 н а є)}=0,84\right.$, $\mathrm{x}_{\text {не знає }}=0,42$ відповідно при $\left.\mathrm{t}=3,63 \mathrm{p}=0,00\right)$; опитаним, які переживали рецидив $\left(\mathrm{x}_{\text {рецидив }}=0,96, \mathrm{x}_{\text {відст рецидив }}=0,77\right.$ відповідно при $\left.\mathrm{t}=2,26 \mathrm{p}=0,03\right)$; дітям із вираженим страхом самотності ( $\mathrm{x}_{\text {вир_cтрах }}=0,90, \mathrm{x}_{\text {не_вир_страх }}=0,45$ відповідно при $\mathrm{t}=6,35 \mathrm{p}=0,00)$, страхом перед майбутнім $\left(\mathrm{x}_{\text {вир страх }}=0,87\right.$, $\mathrm{X}_{\text {не вир страх }}=0,58$ відповідно при $\left.\mathrm{t}=3,94 \mathrm{p}=0,00\right)$, страхом темноти $\left(\mathrm{x}_{\text {вир страх }}=0,94, \mathrm{x}_{\text {не вир страх }}=0,68\right.$ відповідно при $\left.\mathrm{t}=4,39 \mathrm{p}=0,00\right)$, страхом покарання $\quad\left(\mathrm{x}_{\text {вир_cтрах }}=0,69, \mathrm{x}_{\text {не_вир_страх }}=0,90\right.$ відповідно при $\mathrm{t}=-3,36$ $\mathrm{p}=0,00)$, страхом перед болем під час смерті $\left(\mathrm{x}_{\text {вир страх }}=0,90\right.$, $\mathrm{x}_{\text {не_вир_страх }}=0,54$ відповідно при $\left.\mathrm{t}=5,44 \mathrm{p}=0,00\right)$, страхом розлуки 3 батьками після смерті ( $\mathrm{x}_{\text {вир_страх }}=0,83, \mathrm{x}_{\text {не вир_страх }}=0,46$ відповідно при $\mathrm{t}=3,32 \mathrm{p}=0,00)$ та страхом самотності після смерті ( вир_страх $_{\text {ви }}=0,92$, $\mathrm{X}_{\text {не вир страх }}=0,29$ відповідно при $\left.\mathrm{t}=9,6 \mathrm{p}=0,00\right)$.

Також було проведено ряд порівняльних аналізів для опитаних дітей із контрольної групи за схильністю усвідомлювати смертність людини та дитини. На питання анкети «Чи ми безсмертні?» 16 опитаних із контрольної групи відповіли, що «так, безсмертні» та 136 дітей сказали: «ні, не безсмертні». Порівняння дітей із різним відповідним уявленням показало такі відмінності за шкалами: «страх власної смерті» ( $\mathrm{x}_{\text {люди безсм. }}=0,00, \mathrm{x}_{\text {люди смертні }}=0,88$ відповідно при $\mathrm{t}=-10,88 \mathrm{p}=0,00)$, «страх смерті своїх батьків» $\left(\mathrm{x}_{\text {люди безсм. }}=0,38\right.$, $\mathrm{x}_{\text {люди смертні }}=0,96$ відповідно при $\left.\mathrm{t}=-8,74 \mathrm{p}=0,00\right)$, «уявлення про смерть як нерухомість тіла» ( $\mathrm{x}_{\text {люди безсм. }}=0,00, \mathrm{x}_{\text {люди смертні }}=0,29$ відповідно при $\mathrm{t}=-2,56 \mathrm{p}=0,01)$ або «смерть - щось дуже страшне» $\left(\mathrm{x}_{\text {люди безсм. }}=0,50\right.$, $\mathrm{x}_{\text {люди смертні }}=0,06$ відповідно при $\left.\mathrm{t}=6,02 \mathrm{p}=0,00\right)$, «смерть - це сон» $\left(\mathrm{x}_{\text {люди безсм. }}=0,13, \mathrm{x}_{\text {люди смертні }}=0,01\right.$ відповідно при $\left.\mathrm{t}=2,64 \mathrm{p}=0,01\right)$.

Як видно 3 результатів порівняльного аналізу, опитувані 3 контрольної групи, які усвідомлюють смертність людини, характеризуються вищими рівнями схильності до страху власної смерті, також відзначаються уявленням про смерть як про нерухомість тіла, відсутність дихання. Також опитані з контрольної групи, котрі не усвідомлюють смертність людини, вважають смерть чимось дуже страшним або сном. У цих дітей переважає захисний механізм раціоналізації, в інших опитаних із контрольної групи є домінантним захисний механізм заперечення.

На питання анкети «Чи може смерть статися 3 дитиною?» діти 3 контрольної групи розподілилися на 2 підгрупи: 65 осіб відповіли: «ні, не може», 87 - «так, може». Порівняльний аналіз досліджуваних із цих підгруп виявив такі статистично значущі відмінності за шкалами дослідження: «страх власної смерті» $\left(\mathrm{x}_{\text {діти_безсм. }}=0,58, \mathrm{x}_{\text {діти_смертні }}=0,94\right.$ відповідно при $\mathrm{t}=-5,91 \mathrm{p}=0,00)$, «страх смерті батьків» $\left(\mathrm{x}_{\text {діти_безсм. }}=0,83\right.$, 
$\mathrm{x}_{\text {діти_смертні }}=0,94$ відповідно при $\left.\mathrm{t}=-2,24 \mathrm{p}=0,03\right)$, «страх кошмарних снів» ( $\mathrm{x}_{\text {діти_безсм. }}=1,12, \quad \mathrm{x}_{\text {діти_смертні }}=0,80 \quad$ відповідно при $\left.\mathrm{t}=2,13 \mathrm{p}=0,03\right)$, «екзйстенційні страхи» $\left(\mathrm{x}_{\text {діти безсм. }}=1,86, \mathrm{x}_{\text {діти смертні }}=2,14\right.$ відповідно при $\mathrm{t}=-2,23 \mathrm{p}=0,03), \quad$ «хвороба - привид, скелет» ( $\mathrm{x}_{\text {діти безсм. }}=0,02$, $\mathrm{x}_{\text {діти смертні }}=0,09$ відповідно при $\left.\mathrm{t}=-1,99 \mathrm{p}=0,05\right)$, «смерть - це щось дуже страшне» $\left(\mathrm{x}_{\text {діти безсм. }}=0,18, \mathrm{x}_{\text {діти смертні }}=0,05\right.$ відповідно при $\left.\mathrm{t}=2,81 \mathrm{p}=0,01\right)$, «смерть - це кінець життя» $\left(\mathrm{x}_{\text {діти безсм. }}=0,05, \mathrm{x}_{\text {діти смертні }}=0,23\right.$ відповідно при $\mathrm{t}=-3,24 \mathrm{p}=0,00)$. У дітей із різними уявленнями про смертність дитини різняться страхи, які домінують у них. Опитані з контрольної групи, котрі усвідомлюють те, що смерть може статися 3 дитиною, більше за інших бояться власної смерті, смерті своїх батьків, а також відрізняються домінуючими екзистенційними страхами. Аналіз відповідей на питання про хворобу та смерть дозволив виявити уявлення опитаних про ці поняття. Особи, що усвідомлюють свою смертність, вважать хворобу привидом, скелетом, а смерть - кінцем життя, частіше, ніж опитані, які не вважають дітей смертними.

Отже, на першому етапі нашого дослідження ми дослідили уявлення про смерть у дітей молодшого шкільного віку із двох підгруп (пацієнтів із онкогематологічними захворюваннями та дітей із контрольної групи, котрі не мають хронічних захворювань). Можна зробити висновок, що діти 3 онкологічними захворюваннями, які більше усвідомлюють поняття універсальності смерті, уявляють іiі в релігійному контексті більшою мірою, ніж ті, котрі не визнають, що смерть може статися 3 дитиною чи людиною. У ході декількох порівняльних аналізів встановлено, що більше усвідомлення своєї смертності виявлене в онкохворих дітей, які знають про свій діагноз, мають досвід стосунку зі смертю та переживають рецидив. Також ми виявили відмінні домінуючі страхи в опитаних дітей із контрольної групи 3 різним рівнем усвідомлення смертності дитини, а саме схильність до страху власної смерті, смерті батьків, страх кошмарних снів та екзистенційні страхи, що будуть описані в наступному розділі.

\section{2. Переживання страху смерті в дітей у ситуації онкологічного захворювання}

Є. Ільїн описує, що страх смерті вказує на зрілість почуттів, їхню глибину i тому найбільш виражена в емоційно чутливих і вразливих дітей ${ }^{6}$.

У дітей віком 8-10 років, за Бачинським, страх, пов'язаний зі смертю, може виникнути внаслідок конфліктів сумління та почуття

${ }^{6}$ Ильин Е.П. Психология страха. Санкт-Петербург : Издательство «Питер», 2017. 352 c. 
провини. Важливим елементом переживання страху перед смертю в цьому віці є страх незворотного розставання з батьками ${ }^{7}$.

Д. Ісаєв зазначає, що хвора дитина може зрозуміти власну близьку смерть, хоча дорослі хотіли б заперечувати це. Діти, як і дорослі, використовують різні форми психологічного захисту, щоб відвернути таку страшну можливість. Рідко в цьому віці вони прямо говорять про свою боязнь померти ${ }^{8}$.

Д. Шлєповронська, проводячи дослідження дітей у термінальній фазі захворювання, вказала, що діти специфічно описують страх, який супроводжує смерть, котру вони переживають, описуючи це як зникнення 3 поля зору померлого, бездіяльність померлого, смуток, страх, що супроводжує вмирання, причини смерті, власне почуття небезпеки. Також хворі діти менше бояться смерті, ніж здорові. Авторка припускає, що це може бути пов'язано з активізацією захисних механізмів' .

К. де Вальден-Галушко зауважує, що діти по-різному реагують i поводяться перед загрозою смерті, їхня реакція залежить від віку, рис особистості та стосунків, у яких вони залишаються зі своїми близькими. Іноді діти створюють психічні механізми захисту, що дозволяють майже повністю пригнічувати феномен смерті від свідомості, заперечуючи погане самопочуття ${ }^{10}$.

Аналіз малюнків страхів дітей, які хворіють на онкогематологічні захворювання та перебувають на лікуванні від одного до трьох тижнів, показав, що одним із провідних дитячих страхів є страх перед болем, проте результати повторного дослідження, проведеного через 5 місяців, показали, що більшість малюнків містять тему смерті, яка відображається в таких символах, як війна, кладовище, привиди ${ }^{11}$.

На другому етапі нашого дослідження ми дослідили особливості переживання страху смерті у дітей з онкологічними захворюваннями та дітей із контрольної групи. Провели кореляційний аналіз між уявленнями про смерть та особливостями переживання страху смерті.

За допомогою порівняльного аналізу (t-тест Стьюдента) дітей із різних підгруп (досліджуваної та контрольної) встановлені статистично значущі відмінності між ними за уявленнями про смерть та особливостями

7 Binnebesel J. Opieka nad dziećmi i młodzieżą z chorobą nowotworną w doświadczeniu pacjentów. Toruń : Wyd. Uniwersytetu Mikołaja Kopernika, 2003. 333 s.

${ }^{8}$ Исаев Д.Н. Детская медицинская психология. Психологическая педиатрия. Санкт-Петербург : Речь, 2004. 384 с.

${ }^{9}$ Binnebesel J. Opieka nad dzieckiem z chorobą novotvorową. Aspekt pozamedyczny. Toruń : Wydawnictwo Naukowe Uniwersytetu Mikołaja Kopernika, 2000. 210 s.

${ }^{10}$ Binnebesel J. Opieka nad dzieckiem z chorobą novotvorową. Aspekt pozamedyczny. Toruń : Wydawnictwo Naukowe Uniwersytetu Mikołaja Kopernika, 2000. 210 s.

11 Скаковська А.В. Вивчення невербальних страхів у дітей з онкогематологічними захворюваннями. Київський науково-педагогічний вісник. 2019. № 18. C. 116-120. 
переживання страху смерті (рис. 5). Опитані діти 3 онкологічними діагнозами мають більш зрілу форму усвідомлення смертності людини $\left(\mathrm{x}_{\text {онко_діти. }}=0,04, \mathrm{x}_{\text {контр_група }}=0,11\right.$ відповідно при $\left.\mathrm{t}=-2,22 \mathrm{p}=0,03\right)$ та більше

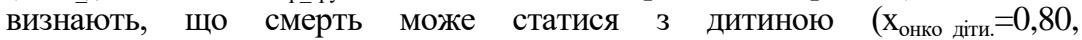
$\mathrm{X}_{\text {контр група }}=0,57$ відповідно при $\left.\mathrm{t}=4,46 \mathrm{p}=0,00\right)$, на відміну від опитаних із контрольної групи. Відносно здоровим дітям із контрольної групи притаманні вищі рівні страху смерті $\quad\left(\mathrm{x}_{\text {онко_діти. }}=0,53, \mathrm{x}_{\text {контр_група }}=0,79\right.$ відповідно при $t=-4,9 \mathrm{p}=0,00$ ) та виражені екзистенційні страхи (самотності та смерті) ( $\mathrm{x}_{\text {онко_діти. }}=1,43, \mathrm{x}_{\text {контр_група }}=2,02$ відповідно при $\mathrm{t}=-6,5 \mathrm{p}=0,00$ ).

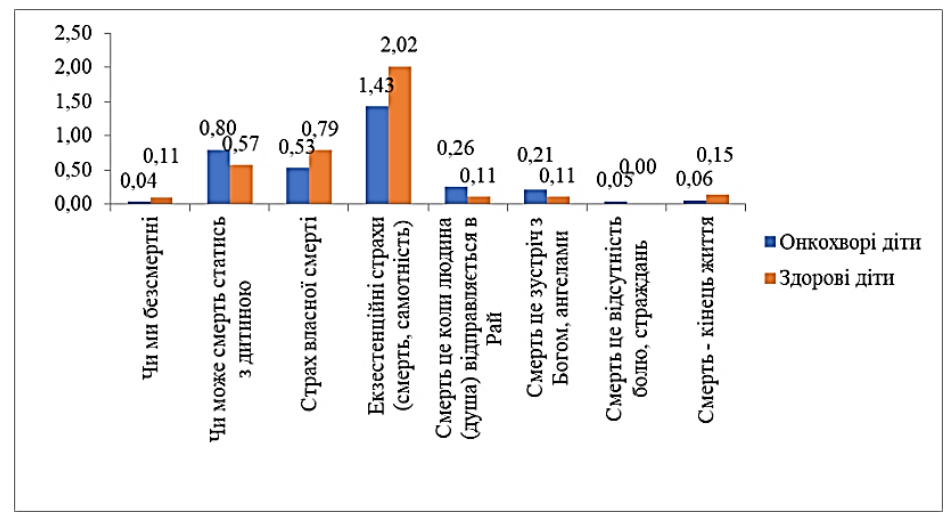

Рис. 5. Результати порівняльного аналізу досліджуваних із досліджуваної та контрольної груп

Також за допомогою порівняльного аналізу виявлені характерні відмінності в уявленнях про смерть у дітей 3 онкологічними діагнозами. Опитані діти з відповідними захворюваннями більше схильні уявляти смерть як «зустріч із Богом, ангелами» $\left(\mathrm{x}_{\text {онко_діт.. }}=0,21\right.$, $\mathrm{x}_{\text {контр_група }}=0,11$ відповідно при $\left.\mathrm{t}=2,35 \mathrm{p}=0,02\right)$, «коли душа вирушає до раю» $\left(\mathrm{x}_{\text {онко_діти. }}=0,26, \mathrm{x}_{\text {контр_група }}=0,11\right.$ відповідно при $\left.\mathrm{t}=3,3 \mathrm{p}=0,00\right)$. Такі відповіді можуть вказувати на те, що онкохвора дитина здатна відчувати певну танатичну тривогу за умов тяжкого захворювання, діти усвідомлюють те, що хвороба може бути смертельною для них і прагнуть продовжувати «життя» в іншому вимірі, оскільки процес помирання не $\epsilon$ природньою ситуацією в розвитку дитини. Також вважають смерть «відсутністю болю, страждань» ( $\mathrm{x}_{\text {онко діти. }}=0,46$, $\mathrm{x}_{\text {контр група }}=0,00$ відповідно при $\left.\mathrm{t}=2,7 \mathrm{p}=0,01\right)$ та «кінцем життя» $\left(\mathrm{x}_{\text {онко_діти. }}=0,06, \mathrm{x}_{\text {контр_група }}=0,15\right.$ відповідно при $\left.\mathrm{t}=-2,7 \mathrm{p}=0,01\right)$. Це може свідчити про інтенсивність болю та страждань, із якими зустрічається дитина під час онкозавхорювання, тоді смерть може уявлятися дитиною як кінець тяжкого захворювання, кінець болючих відчуттів. 
Для більш детального вивчення особливостей переживання страху смерті дітьми 3 онкологічними захворюваннями були проведені кореляційні аналізи та виявлені статистично значущі зв'язки домінуючого страху зі шкалами, які позначають інші страхи, почуття, захисні механізми, особистісні риси та ін. За допомогою кореляційного аналізу (Ч. Спірмена) для групи досліджуваних осіб з онкологічними захворюваннями (152 дитини) встановлено статистично значущі зв'язки психологічних особливостей страхів у досліджуваних дітей $\left(\mathrm{r}_{\text {кр}}=0.22\right.$ при $\left.\mathrm{p}=0,05\right)$.

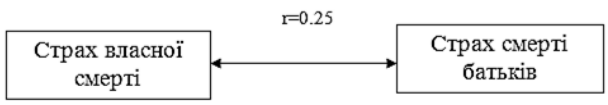

Рис. 6. Статистично значуща кореляція між схильністю опитаних онкохворих дітей переживати страх власної смерті та страхом смерті батьків

У ході кореляційного аналізу виявлено прямий зв'язок між страхом власної смерті у дітей з онкологічними захворюваннями та високим рівнем схильності боятися настання смерті своїх батьків $(\mathrm{r}=0,25)$ (рис. 6). Таким чином, можна припустити, що наявність страху померти у дитини пов'язана з наявністю страху смерті іiі батьків.

Також страх власної смерті прямо корелює із прагненням дитини до домашнього захисту, сімейної згуртованості $(\mathrm{r}=0,31)$ та високим рівнем агресивності $(\mathrm{r}=0,36)$. У ході кореляційного аналізу виявлені обернені статистичні кореляції між високим показником страху власної смерті та низьким рівнем астенії ( $\mathrm{r}=-0,36)$. Це означає, що чим більше опитані діти бояться власної смерті, тим більше їм притаманне прагнення домашнього захисту, сімейної згуртованості, тим більше їм притаманні агресивність і низький рівень астенії (рис. 7).

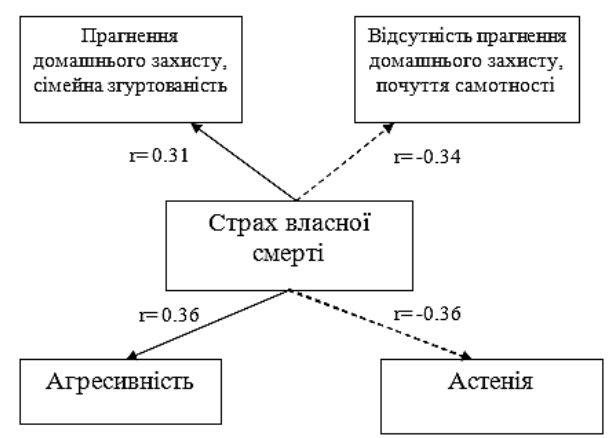

Рис. 7. Статистично значущі кореляції між схильністю опитаних онкохворих дітей переживати страх власної смерті та шкалами проективної методики «Кактус» 
За допомогою кореляційного аналізу виявлено, що високий рівень схильності боятися власної смерті виражається у домінуючих почуттях сорому $(\mathrm{r}=0,53)$ та почутті злості $(\mathrm{r}=0,27)$. Це може бути пов'язано 3 тим, що онкохворі діти бояться власної смерті та можуть переживати сором через власну хворобу, також сором перед своїми батьками через те, що не можуть одужати або можуть померти й таким чином можуть залишити своїх батьків «осиротілими».

Обернені кореляції між страхом власної смерті та почуттям покинутості $(\mathrm{r}=-0,23)$, почуттям самотності $(\mathrm{r}=-0,34)$, почуттям радості $(\mathrm{r}=-0,29)$ означають, що онкохворі діти, які бояться власної смерті, менш схильні почуватися покинутими, самотніми та радісними, проте їм притаманні почуття злості та сорому (рис. 8).

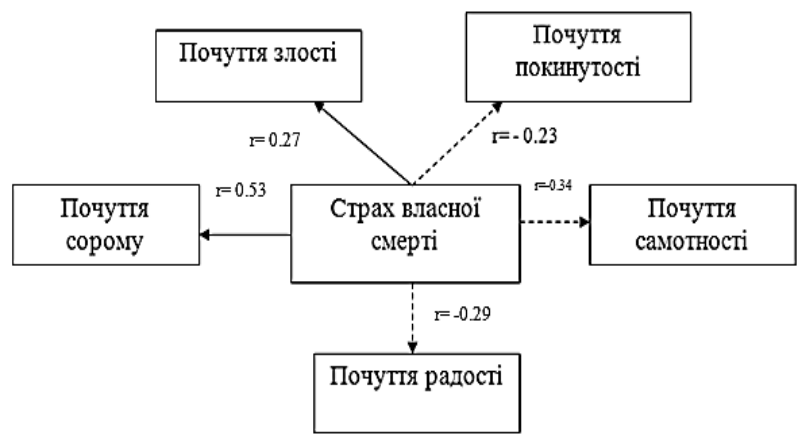

\section{Рис. 8. Статистично значущі кореляції між схильністю опитаних онкохворих дітей переживати страх власної смерті та шкалами авторської анкети «Мої почуття»}

Як видно з рис. 9, виражений страх власної смерті прямо корелює 3 такими адаптивними механізмами, як «проекція» $(\mathrm{r}=0,30)$, «заперечення» $(\mathrm{r}=0,38)$ та «заміщення» $(\mathrm{r}=0,26)$. Також встановлені обернені кореляції між страхом власної смерті та шкалами «витіснення» $(\mathrm{r}=-0,42)$, «фантазія» $(\mathrm{r}=-0,22)$ та «подавлення» $(\mathrm{r}=-0,30)$. Це означає, що дитина, яка характеризується вираженим страхом власної смерті, схильна у подоланні страхів застосовувати механізми проекції, заперечення та заміщення та водночас не характеризується схильністю до таких механізмів, як витіснення, фантазія та подавлення.

Можна припустити, що чим ближче дитина відчуває загрозу власному життю, тим більше здатна витісняти страх смерті за допомогою психологічних механізмів захисту, тим більше спрацьовують такі захисні механізми, як витіснення, фантазія та подавлення, тим менше дитина здатна переживати страх смерті. 
Домінуючий страх власної смерті у дітей 3 онкологічним захворюванням підтверджується наявністю статистичної кореляції із загальним страхом смерті $(\mathrm{r}=0,99)$ і виражається у несхильності до переживання страху самотності $(\mathrm{r}=-0,26)$ та страху, що під час смерті буде боляче $(\mathrm{r}=-0,22)$.

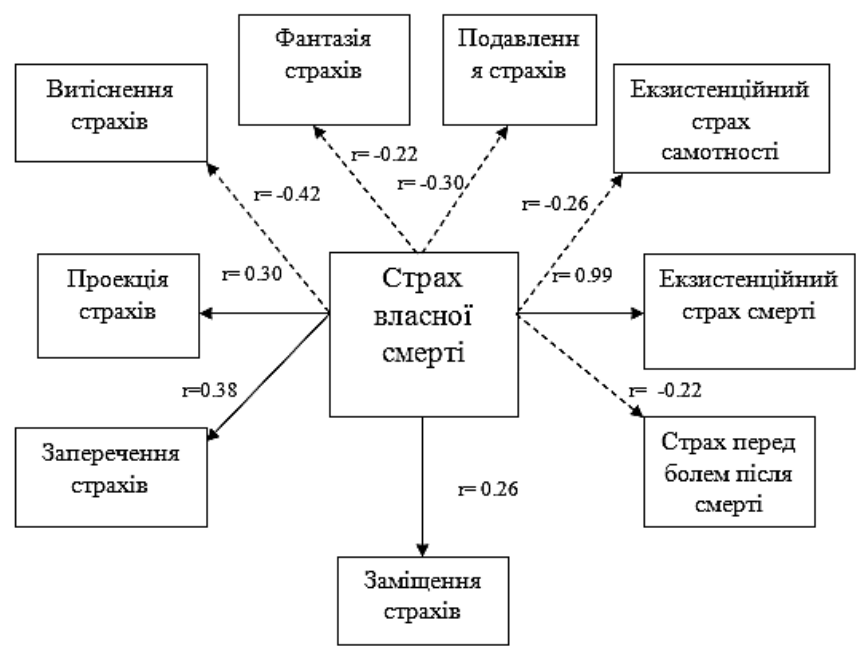

Рис. 9. Статистичні кореляції між домінуючим страхом власної смерті та шкалами методики адаптивних механізмів М. Haworth i шкалами авторського опитувальника дитячих страхів А. Скаковської

За допомогою кореляційного аналізу (Ч. Спірмена) для групи досліджуваних осіб із контрольної групи (152 дитини) встановлено статистично значущі зв'язки психологічних особливостей страхів у дітей, що увійшли до контрольної групи $\left(\mathrm{r}_{\text {кр }}=0.21\right.$ при $\left.\mathrm{p}=0,05\right)$. У ході кореляційного аналізу були виявлені статистично значущі зв'язки віку опитаних, схильності до медичних страхів, страхів фізичних ушкоджень, страхів тварин, казкових персонажів, соціальних страхів, страхів власної смерті, кошмарів, снів, шкільних страхів, страху перед болем, страху бути покинутими та іншими шкалами дослідження.

У ході кореляційного аналізу для опитаних із контрольної групи виявлені статистичні кореляції між домінуванням страху власної смерті та шкалами опитувальника про дитячі страхи А. Скаковської (рис. 10). Виявлено, що домінування страху власної смерті прямо корелює зі страхом зміни зовнішності $(\mathrm{r}=0,28)$ та страхом смерті батьків $(\mathrm{r}=0,40)$. Це означає, що чим більше опитані діти бояться померти, тим більше вони 
переживають страх зміни зовнішності та страх того, що батьки можуть померти. Виражений страх власної смерті обернено корелює зі страхом розчарувати батьків $(\mathrm{r}=-0,24)$, що свідчить про несхильність опитаних до страху розчарувати батьків. Також, як видно з рис. 11, надмірний страх смерті батьків прямо корелює зі схильністю опитаних до регресії $(\mathrm{r}=-0,22)$.

Виражений страх власної смерті корелює зі страхом зміни зовнішнього вигляду $(\mathrm{r}=0,28)$, настання потворства, схильністю до раціоналізації в подоланні страхів $(\mathrm{r}=0,22)$ та страхом розчарувати батьків $(\mathrm{r}=-0,24)$.

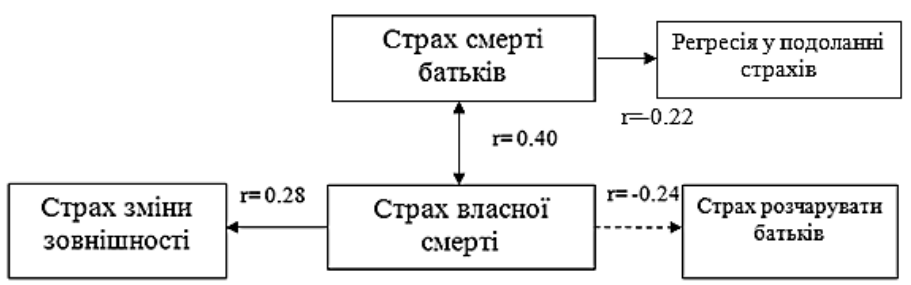

Рис. 10. Статистично значущі кореляції між схильністю переживати страх власної смерті та шкалами анкети опитувальника дитячих страхів А. Скаковської (контрольна група)

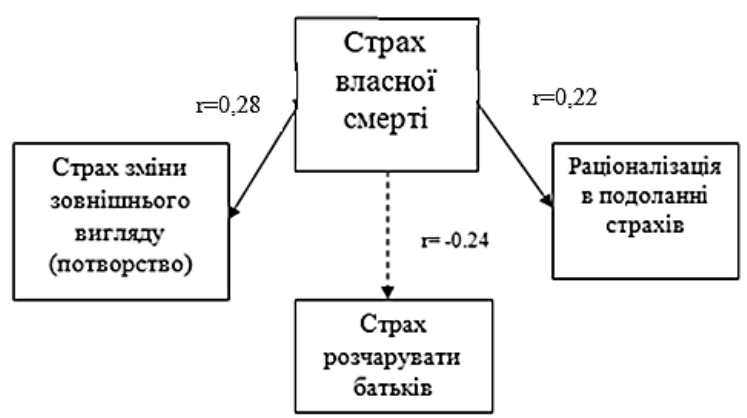

Рис. 11. Статистичні кореляції між страхом власної смерті та шкалами опитувальника дитячих страхів А. Скаковської та шкалами захисних механізмів (контрольна група)

Аналіз кореляційної плеяди з рис. 11 дозволяє підсумувати, що чим більше досліджувані діти 3 контрольної групи бояться померти, тим більший у них страх зміни зовнішності. Також ці діти відзначаються несхильністю до страху розчарувати своїх батьків, у подоланні страхів вони використовують захисний механізм раціоналізації. Аналіз 
кореляційної плеяди дозволяє підсумувати, що чим більше досліджувані діти з контрольної групи бояться померти, тим більший у них страх зміни зовнішності. Також ці діти відзначаються несхильністю до страху розчарувати своїх батьків, у подоланні страхів вони переважно використовують адаптивний механізм раціоналізації.

\section{ВИСНОВКИ}

За даними проведеного дослідження можна зробити такі висновки. Діти 3 онкологічними хворобами мають більш зрілу форму усвідомлення смертності людини та більше визнають, що смерть може статися з дитиною, на відміну від опитаних дітей із контрольної групи. Можна припустити, що уявлення дитини про захворювання та переживання самого онкологічного захворювання сприяє кращому розумінню універсальності смертності. Також на усвідомлення смерті у хворих дітей впливає те, що в онкологічному стаціонарі дитина може зіштовхнутися зі смертю інших дітей у відділенні.

За допомогою порівняльного аналізу виявлені відмінності в уявленні смерті між опитуваними дітьми 3 досліджуваної на контрольної груп. Саме онкохворі діти, на відміну від здорових, більше схильні уявляти смерть як «зустріч із Богом, ангелами», «коли душа вирушає до раю», «відсутність болю, страждань» і «кінець життя». Натомість здорові діти схильні більше уявляти смерть як «нерухомість, відсутність дихання», «кінець життя». Дітям із онкологічними захворюваннями, які вважають, що смерть може статися 3 дитиною, більш притаманно уявляти хворобу в образі «привида, скелета».

Виявлено, що здоровим дітям із контрольної групи притаманні вищі рівні страху смерті, ніж досліджуваним онкохворим. Така тенденція може бути пов'язана з тим, що онкохворі діти знаходяться в реальній ситуації, яка загрожує життю, й використовують механізми психологічного захисту, що допомагають справлятися з екзистенційними страхами та танатичною тривогою.

Виявлені кореляційні зв'язки, які вказують на те, що за вираженого страху власної смерті в онкохворих дітей домінують почуття сорому, почуття злості, прагнення домашнього захисту та сімейної згуртованості, страх смерті батьків. Страх смерті батьків у онкохворих дітей може відображати наявний страх розлуки з батьками.

Встановлено, що чим більше онкохворі діти схильні переживати страх власної смерті, тим більше їм притаманні такі механізми психологічного захисту, як проекція, заперечення та заміщення. Натомість вони не схильні до таких адаптаційних механізмів, як витіснення, фантазія та подавлення.

\section{АНОТАЦІЯ}

У статті розглянуто вікову динаміку стадій розуміння смерті дітьми, наведено результати дослідження розуміння смерті й особливостей 
переживання страху смерті у дітей молодшого шкільного віку, котрі хворіють на онкогематологічні захворювання. Здійснено порівняльний аналіз відмінностей уявлення про смерть у дітей 3 онкогематологічними захворюваннями та здорових дітей, кореляційний аналіз домінуючого страху власної смерті та захисних механізмів, почуттів дітей, психологічних особливостей за шкалами дитячих страхів. Було зроблено висновки про те, що діти 3 онкогематологічними захворюваннями характеризуються більшим усвідомленням смертності, ніж відносно здорові діти з контрольної групи. Встановлено відмінні уявлення про смерть у онкохворих і здорових дітей. Виявлено кореляційні зв'язки, які вказують на те, що за вираженого страху власної смерті в онкохворих дітей домінують почуття сорому, почуття злості, прагнення домашнього захисту та сімейної згуртованості, страх смерті батьків. Встановлено прямий зв'язок між страхом власної смерті у дітей із онкологічними захворюваннями та високим рівнем схильності до страху настання смерті своїх батьків. Також встановлені кореляції вираженого страху власної смерті 3 іншими домінантними страхами, психологічними особливостями особистості та захисними механізмами. Досліджено, що чим більше онкохворі діти схильні переживати страх власної смерті, тим більше їм притаманні такі механізми психологічного захисту, як проекція, заперечення та заміщення.

\section{ЛІТЕРАТУРА}

1. Біннебезель Й., Католик Г. Паліативно-хоспісна опіка: позамедичні багатовимірні аспекти : монографія / за ред. Й. Біннебезель, Г. Католик. Львів : Український Католицький Університет ; Nowa Wieś : Wydawnictwo Rolewski, 2018. 360 c.

2. Ильин Е.П. Психология страха. Санкт-Петербург : Издательство «Питер», 2017. 352 с.

3. Исаев Д.Н. Детская медицинская психология. Психологическая педиатрия. Санкт-Петербург : Речь, 2004. 384 с.

4. Скаковська А.В. Вивчення невербальних страхів у дітей 3 онкогематологічними захворюваннями. Київський науковопедагогічний вісник. 2019. № 18. С. 116-120.

5. Antony S. The discovery of death in childhood and after. Publisher : Basic Books, 1972. 280 p.

6. Binnebesel J. Opieka nad dzieckiem z chorobą novotvorową. Aspekt pozamedyczny. Torun : Wydawnictwo Naukowe Uniwersytetu Mikołaja Kopernika, 2000. $210 \mathrm{~s}$.

7. Binnebesel J. Opieka nad dziećmi i młodzieżą z chorobą nowotworną w doświadczeniu pacjentów. Toruń : Wyd. Uniwersytetu Mikołaja Kopernika, 2003. $333 \mathrm{~s}$. 
8. Gessell A., Ilgs F.L., Ames L.B. The Child from Five to Ten. Published by New York and London : Harper \& Brothers, 1946. 475 p.

9. Nagy M. The child's theories concerning death. The Pedagogical Seminary and Journal of Genetic Psychology. 1948. № 3. P. 3-27. DOI: $10.1080 / 08856559.1948 .10533458$.

\section{Information about the author:} Skakovska A. V., Applicant Ivan Franko National University of Lviv 1, Universytetska str., Lviv, 79000, Ukraine Psychologist Western Ukrainian Specialized Children's Medical Centre 27, Dnisterska str., Lviv, 79035, Ukraine 